\title{
Uprzedzenia Anglików epoki wiktoriańskiej wobec irlandzkich domostw na przykładzie opisu posiadłości Daniela O'Connella w listach komisarza „The Times”
}

Na początku dziewiętnastego wieku istniała w społeczeństwie angielskim ideologia anglosaksonizmu (Anglo-Saxonism). Ideologia ta doszukiwała się korzeni Anglików w dawnych plemionach germańskich, co miało tłumaczyć wspaniałość angielskiej cywilizacji, sukcesy której zostały osiągnięte dzięki cechom i umiejętnością Anglosasów, które należało krzewić wśród innych narodów poprzez Imperium Brytyjskie. Istotnym faktem jest to, że ideologia anglosaksonizmu była wykorzystywana do tego aby pokazać to, że Anglicy różnili się od ras celtyckich, w tym głównie Irlandczyków. Różnica ta była ukazywana i eksponowana poprzez propagowanie obrazu doskonałego Anglosasa i jego całkowitego przeciwieństwa czyli Celta ${ }^{1}$.

Stosunek Anglii do Irlandii powinien być rozpatrywany w kontekście kolonialnym, który został zapoczątkowany w dwunastym wieku. Pomimo Aktu Unii z 1801 roku ustanawiającego Zjednoczone Królestwo Wielkiej Brytanii i Irlandii, Irlandia, jak podaje Christine Kinealy, wciąż była postrzegana jako kolonia, która dodatkowo przez to, że Unia została wymuszona na niej, zajmowała wyjątkowe miejsce w strukturze Imperium Brytyjskiego, szczególnie ze względu na swoje położenie geograficz$n^{2}$. Michael Hechter pisze o Irlandii jako część celtyckiej peryferii i jako idealnym przykładzie wewnętrznego kolonializmu na Wyspach Brytyjskich, dzięki któremu Wielka Brytania mogła nabrać doświadczenia w Irlandii i powielać później politykę kolonialną wobec kolonii zamor-

${ }^{1}$ G. W. Stocking, Victorian Anthropology, New York 1987, s. 62-63, L. P. Curtis, Anglo-Saxons and Celts, Bridgeport 1968, s. 7-8.

${ }^{2}$ C. Kinealy, At Home with the Empire: The Example of Ireland, [w:] At Home with the Empire: Metropolitan Culture and the Imperial World, eds. C. Hall i S. O. Rose, Cambridge 2006, s. 77-78. 
skich. W takiej sytuacji, jak podaje Hechter w celu utrzymania politycznej stabilności metropolia, w tym przypadku Anglia, oprócz użycia siły wykorzystywała szereg stereotypów oczerniających mieszkańców peryferii, tutaj Irlandii3 ${ }^{3}$. Jak podaje Edward Said kolonialnemu dyskursowi przyświecała idea tego, że „«On»i nie są tacy jak «my» i z tego powodu zasługują na to by nimi rządzić"4.

Anty-irlandzki dyskurs na temat Irlandii i jej mieszkańców był rozpowszechniany od czasów Inwazji Normanów za panowania Henryka II (1133-1189) poprzez kolejne dynastie angielskich monarchów5. W związku z tym, że stereotypy o Irlandczykach były szeroko rozpowszechniane specyficzny obraz Irlandii i jej mieszkańców był tak zakorzeniony w umysłach Anglików, że wręcz oczekiwali od nich pewnych typów zachowań, wyglądu czy stylu życia ${ }^{6}$. Wyobrażenia na temat Irlandii i Irlandczyków były tak silne, że na przykład Henry D. Inglis, który odwiedził Irlandię w 1834 roku, opisuje następującą historię o jednym z właścicieli ziemskich:

Byłem bardzo rozbawiony dowiadując się jakiego rodzaju prezenty ten nieobecny właściciel ziemski przywiózł dzieciom i żoną dzierżawców podczas ostatniej wizyty na swojej posiadłości. Uważając, że hrabstwo Waterford, jak i upodobania i potrzeby jego mieszkańców przypominają te istniejące w Nowej Zelandii, dobroduszny, lecz będący w błędzie właściciel ziemski, odwiedził swoje posiadłości z kieszeniami wypełnionymi koralikami, małymi lustereczkami, broszkami i innymi świecidełkami tego pokroju?

3 M. Hechter, Internal Colonialism: The Celtic Fringe in British National Development 1536-1966, London 1975, s. 30, 73, zob. też: C. Hall, The Nation Within and Without, [w:] Defining the Victorian Nation: Class, Race, Gender and the British Reform Act of 1867, eds. C. Hall, K. McClelland i J. Rendall, Cambridge 2000, s. 182-183, 206208, J. H. Ohlmeyer, A Laboratory for Empire? Early Modern Ireland and English Imperialism, [w:] Ireland and the British Empire, ed. K. Kenny, Oxford 2004, s. 26-60.

4 E. W. Said, Kultura i imperializm, przeł. M. Wyrwas-Wiśniewska, Kraków 2009, s. ix.

5 Propagowanie negatywnego obrazu Irlandii wśród Anglików zapoczątkował, mający duży wpływ na kolejnych autorów, dwunastowieczny walijski mnich Giraldus Cambrensis, autor dwóch publikacji o Irlandii Topographia Hibernica i Expugnatio Hibernica, zob. W. R. Jones, „Giraldus Redivivus”-English Historians, Irish Apologists, and the Works of Gerald of Wales, „Éire-Ireland” t. 9, nr 3 1974, s. 3-20, R. N. Lebow, British Historians and Irish History, „Éire-Ireland” t. 8, nr 4 1973, s. 4-7, J. Th. Leerssen, Mere-Irish \& Fíor-Ghael: Studies in the Idea of Irish Nationality, its Development and Literary Expressions Prior to the Nineteenth Century, Philadelphia 1986, s. 35-38, historia antyirlandzkich stereotypów przedstawiona została [w:] L. Curtis, Nothing but the Same Old Story, Belfast 1996.

${ }^{6}$ R. N. Lebow, White Britain and Black Ireland: The Influence of Stereotypes on Colonial Policy, Philadelphia 1976, s. 81.

7 H. D. Inglis, Ireland in 1834: A Journey throughout Ireland, t. 1, London 1835, s. 63-64, wszystkie tłumaczenia autora, chyba, że zaznaczono inaczej. 
W dziewiętnastym wieku jednym z częstych elementów angielskich opisów Zielonej Wyspy, który degradował jej mieszkańców w hierarchii Imperium Brytyjskiego, był portret chat Irlandczyków. Andrew Hadfield i John McVeagh piszą, że wygląd domu irlandzkiego chłopa z jednej strony fascynował, a z drugiej odrzucał angielskiego podróżnika i wskazywał na odmienność kultury irlandzkiej, a „ludzie, którzy żyli w takich warunkach wydawali się dla przeciętnego angielskiego podróżnika, jako posiadający wrodzoną niższość, jeśli nie dzikość”. Anne McClintock pisze, z kolei, że ze względu na to, że Irlandczycy mieli ten sam kolor skóry, co Anglicy, nie można było wykorzystywać tego atrybutu po to, aby ich odseparować od reszty społeczeństwa brytyjskiego. W rezultacie, żeby zdegradować Irlandczyków na sam dół hierarchii imperium na równię z dzikusami przedstawiano ich, jako leniwych, niechlujnych, co było pokazane w wizerunku ich domostw i co McClintock nazywa „domową degeneracją"9.

Poglądy Anglików na temat irlandzkich chat są doskonale widoczne choćby w pierwszym brytyjskim periodyku ilustrowanym, który z powodzeniem wykorzystał technikę grawerowania w drzeworycie „The Penny Magazine" (1832-1845) w artykule na temat pokrywania chat strzechą. Artykuł wskazuje na to, że wygląd domostw jest wyznacznikiem poziomu cywilizacji, rozwoju danego narodu i jego mieszkańców, tym samym wygląd oferowany przez irlandzkie i angielskie domostwa mówi wszystko o ich mieszkańcach i ich sposobie życia ${ }^{10}$. Dom Irlandczyka jest tutaj określony, jako buda, w odróżnieniu od domu Anglika, do którego autor odnosi się, jako schludnej angielskiej chatki, dodając, że:

chaty najbiedniejszych klas irlandzkich chłopów nie są ani schludne ani ciepłe i wygodne jak chaty Nowozelandczyków czy też wielu innych ludzi, których nazywamy dzikusami. Gdyby nie wpływ Chrześcijaństwa na ich moralność, Irlandczycy już dawno zostali pochłonięci przez beznadziejne barbarzyństwo i tylko w tym, nie w ich sytuacji materialnej tkwi ich przewaga nad Nowozelandczykami ${ }^{11}$.

8 A. Hadfield i J. McVeagh, Strangers to that Land: British Perceptions of Ireland from the Reformation to the Famine, Gerrards Cross 1994, s. 252.

9 A. McClintock, Imperial Leather: Race, Gender and Sexuality in the Colonial Contest, New York 1995, s. 53.

${ }^{10}$ Cottages-Thatching, „Penny Magazine”, t. 9, nr 509, 7 marca 1840, s. 93; angielski parlamentarzysta z Carlisle J. C. Curwen, który odwiedził Irlandię w drugiej dekadzie dziewiętnastego wieku napisał z kolei, że „angielski podróżnik przyswaja bardzo niekorzystną opinię o Irlandii patrząc na nędzny stan, w jakim znajdują się domostwa klas niższych, większość, których na pewno wydaje się niegodna zamieszkania przez istoty ludzkie. Z ruin widocznych zewnątrz, natychmiast wysuwa wnioski o nieszczęściach wewnątrz", w: Observations on the State of Ireland, t. 1, London 1818, s. 169.

${ }^{11}$ Cottages-Thatching. 
Przesłanie to, że Irlandczycy nie są wcale bardziej rozwinięci od dzikusów, jest wzmocnione warstwą wizualną artykułu, gdzie mamy przedstawione na jednej stronie dwie ryciny irlandzkich chat i jednej nowozelandzkiej. Za pomocą ułożenia ilustracji mamy przedstawioną hierarchię, w której chata Nowozelandczyków znajduje się na szczycie, a pod nią dwie chaty irlandzkie.

Ważnym elementem dyskursu na temat Zielonej Wyspy w dziewiętnastym wieku stał się Thomas Campbell Foster, komisarz najbardziej wypływowego i opiniotwórczego angielskiego dziennika „The Times”. W sierpniu 1845 roku został wysłany do Irlandii aby poznać sytuację tego kraju i przedstawić jego obraz czytelnikom w serii listów zatytułowanych The Condition of the People of Ireland, które ukazywały się w „The Times” od 21 sierpnia 1845 roku do 20 stycznia 1846 roku. „The Times” pisze $\mathrm{w}$ artykule redakcyjnym, że miało to być alternatywą dla formalnych raportów rządowych takich jak raport Komisji Devona, którym brakowało osobistych i dramatycznych elementów oraz nieformalnej i nieregularnie ukazującej się literatury podróżniczej, której wadą był brak bezstronnośćc ${ }^{12}$. Listom Fostera co prawda nie brakuje dramatyczność, ale daleko im od obiektywności, a obraz Irlandii przedstawił wykorzystując znane na jej temat stereotypy i uprzedzenia. Leslie Williams zwraca także uwagę, że część listów tak bardzo przypomina krytykowane przez „The Times” publikacje podróżnicze i oficjalne sprawozdania, że można wątpić w to, że komisarz zadał sobie w ogóle trud aby udać się osobiście w miejsca, które opisuje ${ }^{13}$. W kwietniu 1846 roku listy uzupełnione o dodatkowe komentarze zostały opublikowane $\mathrm{w}$ formie książki ${ }^{14}$. Co istotne, listy komisarza ukazały się w okresie, kiedy Irlandię zaatakowała zaraza ziemniaczana, która wywołała Wielki Głód Irlandzki (1845-1852), którego rezultatem była śmierć około miliona i emigracja kolejnego półtora miliona Irlandczyków.

Szczególnie duże zainteresowanie angielskiej opinii publicznej wzbudził negatywny opis posiadłości irlandzkiego patrioty walczącego

12 „The Times”, 21 August 1845, s. 4.

13 L. Williams, Bad Press: Thomas Campbell Foster and British Reportage on the Irish Famine 1845-1849, [w:] Nineteenth-Century Media and the Construction of Identities, eds. L. Brake, B. Bell i D. Finkelstein, Houndsmill 2000, s. 298, „The Times” odrzuca ówczesne zarzuty mówiące o tym, że obserwacje jego komisarza nic nie wnoszą, a są wręcz zaczerpnięte z raportu Komisji Devona pisząc, że sq one najbardziej przekonywujacymi $i$ celnymi rzeczami, które kiedykolwiek zostały opublikowane na temat ważnej, irlandzkiej kwestii, [w:] „The Times”, 2 October 1845, s. 5.

14 Zob. T. C. Foster, Letters on the Condition of the People of Ireland, London 1846; o opublikowanym zbiorze listów Fostera „The Times” pisze jako bez wątpienia najciekawszej i najbardziej użytecznej publikacji, która do tej pory ukazała się na temat irlandzkiej kwestii, zob. „The Times”, 15 April 1846, s. 4. 
o niepodległość Irlandii Daniela O’Connella, który pojawił się 18 listopada 1845 roku w liście Fostera. Opis posiadłości O’Connella poprzedza stereotypowy portret w pół nagich, żywiących się ziemniakami mieszkańców hrabstwa Kerry, którzy są ukazani jako porywczy i szybko ulegający emocjom. Domostwo mieszkańca Kerry Foster opisuje następująco:

W norze niczym chlew, w której nie można stanąć wyprostowanym, bez komina, ani bez okna, wyłącznie w jednym pokoju z żelaznym garnkiem i prymitywnym stelażem z słomianą ściółką, łóżkiem lub przykryciem jako jedynymi meblami, pośród pół tuzina prawie nagich dzieci i z bosą żoną siedzi przykucnięty robotnik na klepisku przed ogniskiem z torfu ${ }^{15}$.

Foster podważa również prawo mieszkańców do samorządności pisząc, że Irlandczyk jest „bezradny jak dziecko jeśli chodzi o plan lub pomysł[owość], dzięki którym miałby osuszyć swoją ziemię, lub które miałyby mu pomóc w łowieniu ryb, lub ulepszyć jego chatę czy ocalić jego chore ziemniaki"16. Komisarz pisze o O'Connellu jako obszarniku i w dwóch trzecich pośredniku, czyli postaciom powszechnie demonizowanych i uważanym za odpowiedzialne za fatalną sytuację w Irlandii, który dodatkowo pozwala swoim dzierżawcom i poddzierżawcom na stawianie chat gdzie chcą i dzielenie ziemi jak chcą, co było uważane za jeden z powodów opłakanej sytuacji w Irlandii. Następnie w liście podany jest typowy dla Irlandii opis zaniedbanych i prymitywnych domostw chłopów mieszkających na ziemiach O’Connella. Dalej Foster pisze, że „wśród najbardziej niedbałych właścicieli ziemskich, którzy są przekleństwem Irlandii, Daniel O’Connell jest na pierwszym miejscu - że na posiadłości Daniela O’Connella znajdują się najnędzniejszy dzierżawcy jakich można znaleźć w całej Irlandii”" ${ }^{17}$. Dwa dni po ukazaniu się listu komisarza „The Times” podaje, że jego wysłannik jedynie potwierdził co do tej pory słyszano o ziemiach O'Connella. W artykule zawarte są ostre słowa krytyki wobec O’Connella za jego czynsz, który zbierał dla Stowarzyszenia na Rzecz Odwołania Unii (Repeal Association), a który w tym roku miał przekroczyć 20,000 funtów, w okresie kiedy podstawowy produkt żywieniowy jego rodaków został praktycznie zniszczony i kiedy rząd starał się zapobiec nieuniknionemu głodowi. W tym samym czasie, jak podaje „The Times” kiedy biedni Irlandczycy są na skraju głodu irlandzki patriota wydziera od nich pieniądze na samobójczy cel odwołania Unii, za które mogliby kupić chleb dla swoich dzieci lub uchronić się

15 T. C. Foster, The Condition of the People of Ireland, „The Times”, 18 November 1845, s. 8.

16 Tamże.

17 Tamże. 
przed śmiertelnymi chorobami. Irlandia przedstawiona jest jako anomalia gdzie szarlatan pokroju O'Connella jest opłacany, kiedy to w Anglii zostałby dawno przegnany. Dziennik stwierdza, że jest to oburzający przykład oszustwa, bezduszności i hipokryzji i dodaje, że kiedy na pewno należy się spodziewać jakiejś formy pomocy dla Irlandczyków, należy uważać aby pieniądze publiczne nie zostały użyte do „wzbogacenia funduszy zdzierczego i bezdusznego demagoga"18. O'Connell odparł oskarżenia pod jego adresem ze strony komisarza "The Timesa” w przemowie, której transkrypcja została opublikowana w „The Times” i w której określa on Fostera „komisarzem brukowca”19.

W grudniowym numerze „The Times” Foster poświęca sporo uwagi na krytykę O'Connella, odpowiadając na jego obronę wobec wysuniętych zarzutów dotyczących zaniedbania jego ziem. Foster pisze, że pozytywny obraz posiadłości, który O’Connell przedstawił w swojej mowie po jego poprzednim liście to praktycznie same bzdury i to co zostało napisane w jego liście to czysta prawda. Komisarz proponuje, żeby uwiarygodnić jego opis poprzez wybranie dwunastu dżentelmenów, sześciu przez niego i sześciu przez O’Connella, z różnych części Irlandii żeby potwierdzili i ujrzeli się na własne oczy ziemie Irlandczyka, „ich zrujnowanie - ich brud i calkowite zaniedbanie i nędze ludzi pozostawionych $\mathrm{w}$ stanie pierwotnym, niewykształconych, zlekceważonych, żeby się mnożyli w biedzie" 20 . Pod koniec miesiąca pojawił się w "The Times” również obszerny list syna O’Connella Maurice’a, w którym broni honoru ojca pisząc między innymi o tym, że Foster w tak krótkim czasie nie mógł wyrobić sobie opinii o ziemiach jego ojca i ludzie, którzy udzielili mu informacji nie byli obiektywni. W tym samym numerze „The Timesa” w artykule redakcyjnym, w którym cytowane są fragmenty listów komisarza i listu M. O'Connella, obrona syna O'Connella została skutecznie skrytykowana ${ }^{21}$.

Jeszcze w grudniu ukazał się następny list komisarza, w którym ponownie przedstawia on negatywny obraz posiadłości O’Connella porów-

18 „The Times”, 20 November 1845, s. 4.

19 Ireland: Repeal Association, „The Times”, 26 November 1845, s. 5, zarzuty dotyczące fatalnego stanu posiadłości O'Connella, odpiera też O'Connell, jak i jego syn Maurice w listach opublikowanych na łamach „The Timesa”, gdzie ten drugi pisze, że dzierżawcy ojca żyją w dobrych warunkach, ale istnieje też wielu nielegalnych mieszkańców, których domostwa są w złym stanie, zob. Ireland: The O'Connell Family, „The Times", 28 November 1845, s. 6.

${ }^{20}$ T. C. Foster, The Condition of the People of Ireland, „The Times”, 3 December 1845, s. 4 .

${ }^{21}$ Por. „The Times”, 20 December 1845, s. 4, Mr. O'Connell and the Times Commissioner, „The Times”, 20 December 1845, s. 3. 
nując niektóre domostwa do wigwamów czy chlewów, które odwiedził on tym razem $\mathrm{w}$ celu uwiarygodnienia jego poprzednich opisów wraz z reporterem "The Timesa" pochodzacym z Irlandii i znanym przede wszystkim ze swoich późniejszych reportaży z Wojny Krymskiej Williamem Howardem Russellem. Pomimo tego, że wysłannikom „The Timesa” towarzyszył sam M. O’Connell Foster pisze, że po zwiedzeniu całych Wysp Brytyjskich „w żadnej części Zjednoczonego Królestwa nie ma tak zaniedbanej niedoli-takiego brudu, ubóstwa, wszelkiego rodzaju nędzy - jakie widziałem tego dnia na posiadłości Pana O’Connella, w obecności Pana Maurice'a O'Connella"22. Jeszcze w tym samym miesiącu opublikowano na łamach „The Times” przemowę O’Connella w której krytykuje on kolejny list „The Times” i mówi, że tym razem wysłano dwóch komisarzy brukowca, żeby powiększyć ilość oczerniającego go tekstu i zostały opisane tylko najgorsze chaty, a pominięto te $\mathrm{w}$ dobrym stanie ${ }^{23}$. Na początku stycznia 1846 roku na łamach „The Timesa” pojawił się następny list M. O'Connella, w którym staje w obronie honoru ojca. Niemniej jednak, publikując treść listu redakcja „The Timesa” podważa argumenty syna irlandzkiego patrioty w artykule redakcyjnym, pisząc, że rolą gazety jest „wypełnianie stałego i niezmiennego postanowienia ujawnienia podłych oszustw człowieka, który przez lata był przekleństwem swojego kraju i czymś więcej niż plagą i klęską głodu, zarazą Irlandii”"24.

Popularność listów Fostera jest widoczna między innymi na łamach bardzo popularnego wówczas periodyku ilustrowanego „Puncha”, który w jednym z tekstów parodiuje listy Fostera opisując Irlandię w listach od swojego fikcyjnego komisarza Narcissusa Pinka. Do publikacji dołączony jest stereotypowy rysunek Irlandczyka palącego fajkę z pałką pod pachą przeganiającego świnie, a na rysunku widnieją jeszcze symbolizujące przemoc skrzyżowany sztylet z pistoletem. „Punch” pisze, że ma nadzieję, że O'Connell będzie zadowolony z tekstu jego komisarza, który w przeciwieństwie do komisarza „The Timesa” opisuje Irlandię ironicznie w samych superlatywach pisząc o pięknych Irlandkach czy o schludnych chatach. Wspomniane są tutaj również często krytykowane przez angielskich podróżników trzymane przed domami kupy gnoju, które w rzeczywistości były doskonałym nawozem dla ziemniaków i świnie trzymane w domach, o których „Punch” pisze szyderczo, że kiedy dla Anglika byłoby to odrażające w Irlandii gnój „paruje słodkimi aromatami”,

${ }^{22} \mathrm{Mr}$. O'Connell and the Condition of his Tenantry, „The Times”, 25 December 1845 , s. 5 .

23 Ireland: Repeal Association, „The Times”, 31 December 1845, s. 7.

24 „The Times”, 2 January 1846, s. 4, Ireland: Repeal Association, „The Times”, 2 January 1846, s. 5 . 
a irlandzkie świnie „zachowują się stosownie”25. Dodatkowo opisy posiadłości O’Connella skłoniły rysownika „Puncha” Williama Newmanna do wykonania szczególnie złośliwej ryciny The Real Potato Blight of Ireland $^{26}$. Na rysunku irlandzki polityk został ukazany jako opasły kartofel siedzący na krześle, przed którym znajduje się talerz wypełniony monetami, co odnosi się ponownie do zbieranego przez O'Connella czynszu. Ilustracja ma przedstawiać prawdziwą zarazę ziemniaczaną w postaci O'Connella, co sugeruje, że to on jest odpowiedzialny za sytuację Irlandii.

W związku z tym, że relacje z ziem O'Connella wzbudziły tak duże zainteresowanie popularny tygodnik ilustrowany „The Illustrated London News" postanowił wysłać na miejsce swojego rysownika, który wykonał szkice posiadłości. Serii ośmiu rysunków poświęcono aż dwie strony periodyku. Pomimo tego, że wizualnie ryciny nie przedstawiają negatywnie wizerunku ziem irlandzkiego polityka, są dołączone do nich obszerne i nieprzychylne cytaty z listów Fostera. Ilustracje, które pojawiły się w „The Illustrated London News” zostały skomentowane przez „The Timesa", który pisze, że schlebia mu to, że opisy ich komisarza wzbudziły takie zainteresowanie, że samo „The Illustrated London News” wysłało swojego artystę. Gazeta podkreśla, że najważniejszym rezultatem dochodzeń komisarza jest to, że cały świat może ujrzeć obłudę irlandzkiego patrioty, a teraz dzięki ilustrowanemu tygodnikowi mamy „obraz, zarówno wewnątrz jak i zewnątrz, nędznych nor jego dzierżawców”"27. „The Times" pomimo, że chwali ryciny ilustrowanego tygodnika zwraca uwagę, że nie oddają w pełni nędzy domostw Irlandczyków tam mieszkających ponieważ „miłą słabością rysowników jest schlebianie”28. By udowodnić swoją rację „The Times” odwołuje się do spisu ludności z 1841 roku, który podaje, że na ziemiach praktycznie w całości należących do O'Connella, z 854 znajdujących się tam domów 634 to lepianki nie posiadające okien. Następnie „The Times” komentuje grafikę przedstawiającą wnętrze jednej $\mathrm{z}$ chat, gdzie podaje, że nie jest to możliwe aby jakakolwiek chata była dwukrotnie szersza niż długość krowy, a na rysunku przedstawiającym wnętrze chaty znajduje się jednak „krowa i świnia i próżniacy” [Irlandczycy] ${ }^{29}$. Dodatkowo, dziennik pisze, że narysowany dach chaty „z precy-

25 Ireland, „Punch”, t. 9, July-December 1845, s. 176, W. H. A. Williams, Tourism, Landscape, and the Irish Character: British Travel Writers in Pre-Famine Ireland, Madison 2008, s. 93-94.

${ }^{26}$ The Real Potato Blight of Ireland, „Punch”, t. 9, July-December 1845, s. 255, zob. też: Nothing Extraordinary, „Punch”, t. 10, January-June 1846, s. 24; Derrynane Beg, „Punch”, t. 10, January-June 1846, s. 52.

${ }_{27}^{27}$ Darrynane Beg and Cahirciveen „Illustrated”, „The Times”, 12 January 1846, s. 5.

28 Tamże.

29 Tamże. 
zyjnie ułożonymi belkami jest pokazany tak jak «powinien być» raczej niż «jak jest» i tylko angielska wyobraźnia artysty wstawiła miotłę wewnątrz - przedmiot, którego wieśniak z Kerry prawdopodobnie nigdy nie widział, a z całą pewnością nigdy nie używa" 3 .

Ryciny przedstawiające ziemie O’Connella pojawiły się również w styczniu i lutym 1846 roku w rywalizującym wówczas z „The Illustrated London News” czasopiśmie „The Pictorial Times”. Rysunki, nie będąc nieprzychylnymi dla O'Connella zostały odpowiednio skomentowane przez „The Times”. Po raz kolejny gazeta podważa wiarygodność szkiców pisząc, że w przypadku rysowników „wątły ołówek pomija-nie jest w stanie w rzeczywistości opisać tego co jest przed nim - nie jest w stanie uchwycić istotnych kwestii i z reguły rysownicy dążą do «robienia obrazków» - nie ważne jaka tematyka, wciąż starając się o «ładny» obrazek" ${ }^{1}$.

Odnosząc się do krytyki Fostera wobec O’Connella jako właściciela ziemskiego Michael MacDonagh podaje, że komisarz „The Timesa”, podobnie jak inni angielscy podróżnicy, nie znał i nie rozumiał zwyczajów życia Irlandczyków, postrzegał wszystko powierzchownie i w związku z tym, że niektórzy z Irlandczyków żyli w nędznych warunkach wysunął zbyt pochopne i ogólne wnioski, a O’Connell bez wątpienia był dobrodusznym i wyrozumiałym właścicielem ziemskim ${ }^{2}$. Podobnie Maurice R. O'Connell, historyk i praprawnuk O'Connella, pisze, że O'Connell był dobrym i sprawiedliwym właścicielem ziemskich, który w czasie gdy pojawiła się zaraza ziemniaczana wykazał się troską kupując i rozdając pożywienie dla swoich dzierżawców na własny koszt33. M. R. O’Connell zwraca też uwagę na list angielskiego kwakra William E. Forstera, który odwiedził posiadłości O’Connella wrześniem 1846 roku i napisał, że opisy komisarza „The Timesa” są nieuczciwe i nieprawdziwe, a O'Connell jest najlepszym właścicielem ziemskim w regionie34.

Patrząc na różnice pomiędzy opisami Fostera a graficznymi wizerunkami posiadłości O’Connella w ilustrowanych periodykach i biorąc pod uwagę anty-irlandzką politykę dziennika i niechęć wobec O'Connella, którego raz „The Times” określił jako szumowinę z irlandzkich bagien listy komisarza „The Times” wydają się mało wiarygodne, nie mówiąc

30 Tamże.

${ }^{31}$ The „Picture Times” and the Tenatry of Mr. O'Connell, „The Times”, 3 February 1846, s. 3 .

$3^{2}$ M. MacDonagh, Daniel O'Connell and the Story of Catholic Emancipation, Dublin 1929, s. 340.

33 M. R. O'Connell, O'Connell: Lawyer and Landlord, [w:] Daniel O'Connell: Portrait of Radical, eds. K. B. Nowlan i M. R. O'Connell, Belfast 1984, s. 116-119.

34 T. Wemyss Reid, Life of the Right Honourable William Edward Forster, London 1889, s. 100, 102. 
obiektywne35. Doskonale widać tutaj uprzedzenia angielskiego społeczeństwa wobec Irlandczyków ukazane poprzez przedstawianie nieprzychylnych obrazów irlandzkich domostw, co wskazywało na niższość i inność celtyckich sąsiadów, co za tym idzie ich niezdolność do samorządów. Co istotne, patrząc na to jaką popularność wzbudziły listy i status „The Timesa", który był wówczas najbardziej wpływową i opiniotwórczą gazetą, negatywny wizerunek irlandzkiego patrioty i irlandzkiego społeczeństwa zawarte $\mathrm{w}$ listach nie wzbudził z pewnością sympatii do Irlandii i jej mieszkańców wśród angielskich czytelników dziennika. Nieprzychylne Irlandczykom listy były szczególnie destruktywne dla Irlandii ukazując się w czasie kiedy zaatakowała ją zaraz ziemniaczana, która pozbawiła dużą część Irlandczyków jedynego produktu żywieniowego i stała się jedną z największych katastrof w historii Zielonej Wyspy.

\section{Bibliografia}

Curtis, Lewis P., Anglo-Saxons and Celts, The Conference on British Studies at the University of Bridgeport, Bridgeport 1968.

Curtis, Liz, Nothing but the Same Old Story, Sásta, Belfast 1996.

Curwen, John C., Observations on the State of Ireland, t. 1, Baldwin, Cradock, and Joy, London 1818.

Foster, Thomas C., Letters on the Condition of the People of Ireland, Chapman and Hall, London 1846.

Hadfield, Andrew i John McVeagh, Strangers to that Land: British Perceptions of Ireland from the Reformation to the Famine, Colin Smythe, Gerrards Cross 1994.

Hall, Catherine, The Nation Within and Without, [w:] Defining the Victorian Nation: Class, Race, Gender and the British Reform Act of 1867, eds. C. Hall, K. McClelland i J. Rendall, Cambridge University Press, Cambridge 2000.

Hechter, Michael, Internal Colonialism: The Celtic Fringe in British National Development 1536-1966, Routledge \& Kegan Paul, London 1975.

Inglis, Henry D., Ireland in 1834: A Journey throughout Ireland, t. 1, Whittaker \& Co., London 1835 .

Jones, William R., „Giraldus Redivivus” - English Historians, Irish Apologists, and the Works of Gerald of Wales, „Éire-Ireland” t. 9, nr 3, 1974.

Kinealy, Christine, At Home with the Empire: The Example of Ireland, [w:] At Home with the Empire: Metropolitan Culture and the Imperial World, eds. C. Hall i S. O. Rose, Cambridge University Press, Cambridge 2006.

Lebow, Richard N., White Britain and Black Ireland: The Influence of Stereotypes on Colonial Policy, Institute for the Study of Human Issues, Philadelphia 1976.

Lebow, Richard N., British Historians and Irish History, „Éire-Ireland” t. 8, nr 4, 1973.

35 Zob. The Whig Missionary of 1835, „The Times”, 26 November 1835, s. 5 . 
Leerssen, Joseph Th., Mere-Irish \& Fíor-Ghael: Studies in the Idea of Irish Nationality, its Development and Literary Expressions Prior to the Nineteenth Century, John Benjamins Publishing Company, Philadelphia 1986.

MacDonagh, Michael, Daniel O'Connell and the Story of Catholic Emancipation, The Talbot Press, Dublin 1929.

McClintock, Anne, Imperial Leather: Race, Gender and Sexuality in the Colonial Contest, New York 1995.

O'Connell, Maurice R., O'Connell: Lawyer and Landlord, [w:] Daniel O'Connell: Portrait of Radical, eds. K. B. Nowlan i M. R. O'Connell, Appletree Press, Belfast 1984.

Ohlmeyer, Jane H., A Laboratory for Empire? Early Modern Ireland and English Imperialism, [w:] Ireland and the British Empire, ed. K. Kenny, Oxford University Press, Oxford 2004.

Said, Edward W., Kultura i imperializm, przeł. M. Wyrwas-Wiśniewska, Wydawnictwo Uniwersytetu Jagiellońskiego, Kraków 2009.

Stocking, George W., Victorian Anthropology, The Free Press, New York 1987.

Wemyss Reid, T., Life of the Right Honourable William Edward Forster, Chapman and Hall, London 1889.

Williams, Leslie, Bad Press: Thomas Campbell Foster and British Reportage on the Irish Famine 1845-1849, [w:] Nineteenth-Century Media and the Construction of Identities, eds. L. Brake, B. Bell i D. Finkelstein, Palgrave Macmillan, Houndsmill 2000.

Williams, William H. A. Tourism, Landscape, and the Irish Character: British Travel Writers in Pre-Famine Ireland, University of Wisconsin Press, Madison 2008. 